\title{
TEATRO E EDUCAÇÃO: UMA RELAÇÃo HISTORICAMENTE CONSTRUÍDA
}

\author{
THEATER AND EDUCATION: \\ A RELATIONSHIP HISTORICALLY CONSTRUCTED
}

\author{
Talitha Cardoso Hansted \\ Profa de Teatro do Instituto Educacional Imaculada/Campinas, \\ Diretora de teatro, Atriz, Mestrado Faculdade de Educação/Unicamp. \\ talithacardoso@yahoo.com.br
}

\begin{abstract}
Maria da Glória Gohn
Profa do PPGE em Educação da UNINOVE e da UNICAMP. Pesquisadora I do CNPq.Área da Sociologia e Educação ( movimentos sociais, políticas públicas e educação não formal. Vice-Presidente do

Research committee Social Movements and Social Classes da Associação Internacional de Sociologia. mgohn@uol.com.br
\end{abstract}

\begin{abstract}
Resumo: Este trabalho apresenta uma breve retrospectiva das relaçóes entre teatro e educação ao longo da História, destacando algumas das principais tendências pedagógicas com a linguagem teatral. A apresentaçâo está dividida em duas partes: a primeira explora as relaçóes entre teatro e educação desde a Antiguidade até os dias atuais, valendo-se de algumas das principais contribuiçóes de pensadores que teceram consideraçóes a respeito do potencial educativo do teatro; a segunda parte focaliza o contexto brasileiro, apontando para uma vasta multiplicidade teórica e metodológica de abordagens, e indicando a necessidade de uma maior valorização da prática teatral na escola básica, na atualidade. Dentre as principais conclusôes, o trabalho destaca que ainda que os Parâmetros Curriculares Nacionais garantam a presença do teatro na escola, há muito para ser discutido e aprimorado, para que as potencialidades dessa arte sejam exploradas e aproveitadas como contribuição significativa à formaçáo dos alunos e à educação brasileira.
\end{abstract}

Palavras-chave: Educação. História. Teatro. Teatro-Educação.

\begin{abstract}
Aвstract: This paper presents a brief review of the relationship between theater and education throughout history, highlighting some of the major trends in drama education. The presentation is divided in two parts: the first explores the relationship between theater and education from Antiquity to the present day, taking advantage of some of the major contributions of thinkers who explored the educational potential of theater; the second part focuses on the Brazilian context, pointing to a wide variety of theoretical and methodological approaches, and indicating the need for a greater appreciation of theatrical practice in schools. Among the key findings, the paper highlights that although the National Curriculum Parameters guarantee the presence of theater in school, there is much to be discussed and improved, so that the potential of this art is explored as a significant contribution to the development of students and Brazilian education.
\end{abstract}

KeY-wORDs: Education. History. Theater. Theater Education. 


\section{Teatro e educaçáo: breve sinopse}

A pesquisa da qual faz parte este texto tem como objetivo investigar o papel de atividades de teatro, desenvolvidas em uma escola de ensino básico, na formação da cidadania. Para tanto, abordamos algumas relaçóes entre teatro e educação que se foram estabelecendo ao longo da História, inclusive as principais contribuiçôes de filósofos e pensadores a respeito do tema. Estamos concebendo a educação em sentido amplo, englobando tanto a formal, escolar, quanto a não formal, extraescolar.

Isso posto, iniciamos nosso panorama histórico apresentando o teatro como uma arte cujas origens remontam ao surgimento da raça humana. Das manifestaçóes do homem primitivo - que tinha o costume de simular caças, imitar animais e personificar os espíritos em que acreditava - às mais modernas formas de representação, essa linguagem artística sofreu diversas modificaçóes, mas sempre ocupou o seu lugar na história do ser humano. $\mathrm{Na}$ verdade, o teatro continuamente refletiu o momento social e os pensamentos de cada época (BERTHOLD, 2006).

Por estar o teatro tão vinculado à história da humanidade, não é de se espantar que seu potencial educativo tenha sido explorado desde a Antiguidade. Courtney (I980), ao expor um amplo painel histórico e filosófico em que apresenta as bases intelectuais do teatro na educação, destaca que já no século V a.C., a educação ateniense estava baseada em música, esportes e literatura. Nesta última vertente, incluíam-se declamaçôes das obras de poetas - especialmente Homero - com recursos teatrais de inflexão vocal, gestos dramáticos e expressôes faciais. $\mathrm{O}$ próprio teatro - enquanto encenação - é considerado por Courtney como "[...] a maior força unificadora e educacional no mundo ático.” (I980, p.5). Ainda de acordo com o autor, tal relevância é justificada pelo fato de as representaçôes teatrais servirem como veículo de transmissão de conhecimento e constituírem o único prazer literário de que o povo dispunha. Para os romanos, o teatro também podia apresentar propósitos educacionais, desde que transmitisse liçôes morais. No campo da filosofia, Courtney (I980) aponta o grego Aristóteles e o romano Horácio como lançadores das bases para o pensamento humanista no teatro. O primeiro, em sua Poética $(-330$ a.C.), já afirmava que a imitação é natural ao homem e que o ser humano 
aprende por meio dela; o segundo, por sua vez, em Arte poética ( - I8 a.C.), considerava que o teatro deveria tanto entreter quanto educar.

Durante a Idade Média, a Igreja Católica utilizou-se do potencial educativo do teatro com o propósito de aproximar o povo iletrado das histórias e ensinamentos eclesiásticos. Em encenações de caráter litúrgico, como os Mistérios ${ }^{\mathrm{I}}$ e as Moralidades ${ }^{2}$, “[...] personagens bíblicas ganhavam vida e saltavam aos olhos do espectador, fazendo-o compreender de forma mais profunda os mistérios divinos." (SANTOS, 2009, p. 2318). Em uma época em que o acesso a obras literárias era restrito a membros da Igreja, essas encenaçóes tinham um papel educacional de grande relevância, conforme destaca Courtney (I980):

Por cinco séculos, os Mistérios e Moralidades constituíram-se no único prazer intelectual das multidóes. Escolas e livros, a bem da verdade, eram privilégios de poucos. Foi o teatro que propiciou às massas sua educação. (COURTNEY, i98o, p. 9).

No período da Renascença, houve a redescoberta das obras clássicas e a retomada do pensamento humanista. A valorizaçáo da arte do falar, especialmente o latim, levou ao estudo do teatro antigo, o que acabou por favorecer muitas encenaçóes escolares. O movimento teve início na Itália, onde estudantes da Academia Romana de Pomponius Laetus passaram a encenar peças da Antiguidade. No final do século XVI, as atividades dramáticas já estavam presentes em diversas instituiçóes escolares europeias. Nessa época, os estudantes encenavam não apenas obras clássicas, mas também textos ${ }^{3}$ adaptados ou criados por seus professores, mestres e reitores.

Berthold (2006) faz referência a encenações escolares feitas durante o século XVI em diferentes países europeus, como Alemanha, Áustria, Dinamarca, França, Hungria, Inglaterra, Suécia e Suíça. A maior parte desses países, vale mencionar, passara pela Reforma Protestante, cujo principal líder, Martinho Lutero, admitia que o teatro pudesse exercer influência benéfica sobre os alunos tanto na prática da língua latina quanto na transmissão de comportamentos entendidos como socialmente adequados. O drama escolar protestante náo ficava restrito a salas de aula ou pátios das escolas: era também apresentado em auditórios de conferência de universidades, prefeituras, sedes de grêmios, praças públicas, mercados e, até 
mesmo, em palácios. Predominava um tipo de teatro que buscava exercer seu efeito não pelo visual - o palco costumava ser simples e o cenário, único - mas pela palavra: "Era pela declamação alta e audível em latim - mais tarde, língua nacional- que os pedagogos demonstravam suas intençóes didáticas aos pais e autoridades públicas.” (BERTHOLD, 2006, p.303).

Courtney (I980) destaca que, na Inglaterra, as escolas dos Tudor ${ }^{4}$ desenvolveram forte tradição dramática, encorajando o teatro não apenas para estudo das obras clássicas, mas como exercício de linguagem, utilizado para desenvolver a língua materna. Neste ponto, é interessante observar que existem muitos trabalhos contemporâneos na área do teatro-educação que tratam do uso do teatro em escolas, na atualidade, com o fim específico de aprendizagem da língua inglesa. É o caso dos trabalhos de Dora Ton et al. (20II), Dunn e Stinson (20II), Even (20II), Kao; Cark e Hsu (200I) e Ntelioglou (20I I).

Ainda no contexto dos séculos XVI e XVII, Courtney (I980) faz referência a uma série de filósofos e estudiosos que teceram consideraçôes acerca do potencial educativo do teatro: Sir Thomas Elyot, por exemplo, enfatizava a dança dramática na educação; Sir Philip Sidney e Ben Jonson acreditavam que o teatro deveria tanto ensinar quanto divertir; Montaigne defendia que as crianças, mais do que repetir suas liçóes, deveriam atuálas; e Francis Bacon referia-se ao teatro educacional como

[...] uma arte que fortalece a memória, regula o tom e efeito da voz e pronúncia, ensina um comportamento decente para a fisionomia e gestuação, promove a autoconfiança e habitua os jovens a não se sentirem incômodos quando estiverem sendo observados. (apud CORTNEY, i98o, p. I2).

Merece destaque também, nos séculos XVI e XVII, a utilização do teatro, enquanto recurso pedagógico, por parte dos padres da Companhia de Jesus, fundada no ano de I534, por Inácio de Loyola. O’Malley (2004) destaca que os jesuítas cultivaram o drama escolar "[...] num nível especialmente alto por um longo período de tempo, numa vasta rede de colégios quase ao redor do mundo." (p. 34). Tanto que, de acordo com Toledo, Ruckstadter F. M. M. e Ruckstadter V. C. M. (2007), em qualquer parte do mundo onde houve um colégio jesuítico, há referências à utilização do 
teatro enquanto instrumento pedagógico. A encenação de peças teatrais escritas pelos próprios religiosos da ordem constituía um dos principais recursos didáticos de que os jesuítas lançavam mão. As peças teatrais da Companhia de Jesus, tanto na Europa quanto nas colônias, prestavamse à instrução dos alunos e ao ensinamento dos dogmas católicos. Nos países europeus, que viviam o contexto da Contra-Reforma Católica, as encenaçóes nos colégios jesuítas eram realizadas especialmente em dias de festa, e tinham como principal objetivo manter os alunos atrelados à moral cristá. Os estudantes realizavam as encenaçóes não apenas dentro das escolas, mas também nos pátios das Igrejas, para o público em geral. Diferentemente do drama protestante, muitas das encenaçóes jesuítas, no continente europeu, apresentavam ambiciosos cenários, figurinos e truques de ilusionismo.

No Brasil, o teatro foi largamente utilizado pelos jesuítas, como instrumento de catequização dos índios. As peças escritas pelos religiosos 5 da Cia. de Jesus, que figuram entre as primeiras obras teatrais do território nacional, tinham, conforme destaca Magaldi (2004, p. I6), o propósito de "[...] levar a fé e os mandamentos religiosos à audiência, num veículo ameno e agradável, diferente da prédica seca dos sermóes.”. Kassab (20I0) destaca que o teatro jesuítico, no Brasil, se configurava como a melhor possibilidade de atrair os povos nativos, cujos costumes tanto diferiam daqueles apresentados pelos colonizadores. Nesse sentido, vale mencionar que nas encenaçóes promovidas pelos jesuítas em território nacional, notase a incorporação de músicas, danças, instrumentos musicais, adereços e aspectos do cotidiano da vida dos nativos, em uma clara estratégia de aproximação entre as duas culturas.

No século XVIII, de acordo com Courtney (I980), o teatro teve pouco espaço em contextos escolares ${ }^{6}$ no mundo ocidental. Uma das explicaçóes para isso foi o fato de o sistema de raciocínio indutivo de Francis Bacon ter sido amplamente difundido nas escolas. Apesar de o filósofo, conforme explicitado anteriormente, ter apoiado o teatro na educaçáo de jovens, seu método educacional, que propunha o estudo de objetos naturais para chegar à verdade, abria pouco espaço à atividade dramática. A crença de John Locke de que a educação deveria visar à formação de hábitos da mente também contribuiu para que a educação, nesse século, assumisse um aspecto muito mais formal do que liberal. 
No final do século de XVIII e início do XIX, o ensino nas escolas não sofreu grandes alterações, mas sua filosofia sim. Jean-Jacques Rousseau teve fundamental importância nesse processo, visto que colocou a criança no centro do processo educativo e defendeu o jogo como elemento primordial da educação infantil:

Para Rousseau, a primeira educação da criança deveria ser quase que inteiramente através do jogo. Os simples atos de correr, saltar e brincar têm valor. Não haveria repressão e os instintos deveriam ser encorajados (COURTNEY, I980, p. I8).

Rousseau não apoiava especificamente o teatro na educação, mas sua defesa de uma educação pedocêntrica (centrada na criança) e fundamentada no jogo serviu de inspiração a pensadores futuros, que viriam a defender o "jogo dramático" e, mais tarde, o "jogo teatral” mentos efetivos de aprendizagem, conforme veremos mais adiante. No final do século XIX, a teoria evolucionista de Charles Darwin forneceu base científica ao que Rousseau defendia, na medida em que demonstrou que a criança é um ser em desenvolvimento e que cada fase de seu crescimento deve ser estimulada adequadamente (COURTNEY, I980). Neste cenário, apoiado na pedagogia de Rousseau, surge o movimento "Educaçáo Ativa" - ou Escola Nova, como veio a ser conhecido no Brasil -, originalmente liderado pelo norte-americano John Dewey. O movimento, considerado como progressista na época em que surgiu, revolucionou as formas tradicionais de ensino ao colocar a criança no centro do processo educativo, defendendo o respeito ao seu desenvolvimento natural.

É também nessa época que o teatro volta a ter participação importante na educação. Por um lado, há a retomada de encenaçóes de peças em escolas, em especial para estudos de línguas; por outro, emerge uma nova maneira de se pensar atividades ligadas ao teatro em ambientes escolares, alinhada aos postulados do movimento Educação Ativa. Se na visão tradicional, o teatro em escolas resumia-se à montagem de peças, sem o cuidado com a formação do indivíduo, na concepção "escolanovista” o foco passa a ser o desenvolvimento da criança e a livre expressáo de sua imaginação criativa (KOUDELA, I992). Japiassu (2009, p. 24) destaca que é na segunda metade do século XIX que passa a haver uma "[...] literatura caracteri- 
zada como especificamente debruçada sobre o binômio teatro-educação.”. Antes dessa fase, os pensadores que teceram consideraçóes a respeito do teatro na educação o fizeram considerando separadamente cada um desses campos do conhecimento.

No final do século XIX e, em especial, na primeira metade do século XX, diversos autores se debruçam sobre o tema teatro-educação, desenvolvendo abordagens pedagógicas que continuam, até os dias atuais, a influenciar trabalhos na área. É o caso, por exemplo, da norte-americana Winifred Ward (I884-I975), cuja obra reflete os postulados da Escola Nova. A autora enfatiza a importância da expressão criativa da criança, defendendo que o processo do trabalho com teatro em escolas deve ser mais enfatizado que seu produto final (WARD, I957).

Destaca-se também, na primeira metade do século XX, a obra de Caldwell Cook (I885-1939), formulador da ideia de que a atividade dramática poderia ser um método eficiente para aprendizagem de conteúdos escolares diversos (COUTRNEY, I980). Em The Play Way (COOK, I9I7), o professor inglês expôs seu método de abordagem de atividades dramáticas em ambientes escolares, também denominado play way ("método dramático"). Até então, conforme já explicitado, o teatro em escolas consistia apenas em encenaçôes de peças e leituras de diálogos em aulas de língua. Cook propôs uma nova forma de abordagem: para ele, a atuação, por meio do jogo, era um caminho seguro para a aprendizagem, não apenas de línguas. Seu método consistia em utilizar o conteúdo dos livros didáticos de diversas disciplinas como pretexto para que os alunos o encenassem, de forma espontânea (não ensaiada), facilitando, assim, a aprendizagem. Desse modo, na aula de História, por exemplo, os alunos representavam os fatos históricos que estavam sendo trabalhados. Cook, para o desenvolvimento de seu método, partia dos seguintes princípios: de que o aprendizado e a proficiência advêm da experiência e não da escuta ou da leitura; de que o bom trabalho costuma ser resultado do livre interesse e do esforço espontâneo; e de que o jogo é o meio natural de estudo para a juventude (COOK, I9I7). O que o autor propunha era uma encenação livremente improvisada pelos alunos, em sala de aula, sem a intervenção do professor e ausente de preocupaçóes com convençóes teatrais.

$\mathrm{Na}$ década de I950, o pedagogo e teatrólogo inglês Peter Slade (I9I2-2004) publica a obra Child Drama (SLADE, I954), em que defende 
a tese de que "[...] o Jogo Dramático Infantil é uma forma de arte por direito próprio; não é uma atividade inventada por alguém, mas sim o comportamento real dos seres humanos." (SLADE, I978, p. I7). Slade atribui importância tão singular ao "jogo dramático" no desenvolvimento infantil que reivindica para a atividade um espaço próprio no currículo escolar. Assim, ao invés de servir de método de ensino de outras matérias - como propunha Cook -, para Slade, a atividade dramática deveria constituir uma "[...] 'disciplina' independente, com seu próprio lugar no horário escolar." (COURTNEY, I980, p. 46). O autor entendia que uma das principais contribuiçóes do jogo dramático infantil seria o fato de fornecer à criança "[...] uma válvula de escape, uma catarse emocional [...]" (SLADE, I978, p.r8), favorecendo, dessa forma, o desenvolvimento de controle emocional e autodisciplina interna. Child Drama, de acordo com Japiassu (2009), é considerada a obra seminal para a "abordagem pedagógica anglo-saxônica do jogo dramático infantil”, proposta metodológica ainda hoje estudada e utilizada. A "abordagem anglo-saxônica" do teatro na educação, conforme explica o autor, defende que o drama deve ocupar posiçáo central no currículo, constituindo uma espécie de eixo em torno do qual poderiam se articular as demais áreas do conhecimento, a serem trabalhadas de maneira interdisciplinar.

Merece destaque também, na segunda metade do século XX, o "jogo teatral", conceito apresentado em forma de sistema metodológico para o desenvolvimento de trabalho pedagógico com o teatro pela norteamericana Viola Spolin (I906-1994). O sistema de jogos teatrais desenvolvido pela diretora, atriz e professora de teatro foi exposto pela primeira vez no ano I962, em seu livro Improvisação para o teatro (SPOLIN, 2000). Pupo (200I) explica que o sistema de jogos teatrais "caracteriza-se como uma abordagem da improvisação teatral cercada por regras precisas, entre as quais se destacam o acordo grupal, o foco, a instrução e a avaliação" (p. I8I). Apesar de os jogos teatrais serem amplamente utilizados em ambientes escolares até os dias atuais, a obra de Spolin não se dirige apenas aos interessados no trabalho com teatro em escolas, mas a "[...] todos os que desejem se expressar através do teatro, sejam eles profissionais, amadores ou crianças." (KOUDELA, I992, p. 40). A autora parte do princípio de que todas as pessoas podem atuar no palco porque todas são capazes de improvisar. Ao contrário do jogo dramático defendido por Peter Slade, em 
que a criança joga livremente, sem intervenção do professor, no jogo teatral há regras claras, e os jogadores devem estar sempre concentrados na busca de soluçóes para os desafios propostos pelo professor ou coordenador (JAPIASSU, 2009). Outro ponto que o diferencia do jogo dramático é o fato de o jogo teatral visar à aquisição da linguagem cênica e dos princípios básicos do fazer teatral. A didática de Spolin (2000) entende que em situação de jogo, o indivíduo sente-se livre para atuar criativamente, dentro de determinadas limitaçôes - as regras de cada jogo - e que, dessa forma, vai incorporando intuitivamente as técnicas teatrais. Em Improvisação para o teatro (SPOLIN, 2000) e, posteriormente, em Jogos teatrais: o fichário de Viola Spolin (SPOLIN, 200I), a autora apresenta seu sistema na forma de manual, demonstrando como cada um dos jogos teatrais deve ser conduzido, e quais noçóes relacionadas ao fazer teatral cada um deles desenvolve. O sistema de jogos teatrais é, ainda hoje, muito utilizado para o trabalho com atores e náo atores de todas as idades, tendo se tornado um referencial para atores e professores de teatro. No Brasil, a proposta de ensino de Spolin vem sendo bastante investigada, desde os anos i980, conforme veremos adiante.

Caldwell Cook, Peter Slade e Viola Spolin são mencionados por Japiassu (2009), que apresenta um compêndio das principais abordagens pedagógicas de ensino do teatro no Brasil. Outros autores referenciados pelo estudioso, que contribuíram de forma relevante, no decorrer do século $\mathrm{XX}$, para a maneira de se pensar o teatro na educação não apenas no Brasil, mas em todo o mundo, são: Jacob Levi Moreno (I889-I974), psiquiatra romeno que trabalhou o valor terapêutico do teatro, por meio do "psicodrama" e do "sociodrama"; Bertold Brecht (I898-I956), dramaturgo que utilizava o teatro como instrumento de luta política contra as contradiçốes econômicas e sociais da sociedade burguesa, e cujas peças didáticas 9 continuam a influenciar "[...] práticas teatrais educativas de caráter político-estético [...]” (JAPIASSU, 2009, p. 38); e Augusto Boal (I93I-2009), dramaturgo e diretor teatral brasileiro, criador do "teatro do oprimido" ${ }^{\text {Io }}$, cuja pedagogia tem inspirado experimentaçóes e investigações no Brasil e no mundo. Japiassu (2009) faz também menção à "terapia social da performance" "I , desenvolvida nos Estados Unidos por Fred Newman (I935-20II), no decorrer da década de i970 e I980, como área promissora a ser explorada em ambientes educacionais. 
No decorrer do século XX e, mais recentemente, já no século XXI, outros autores contribuíram - e têm contribuído - de forma relevante para a maneira de se pensar o teatro na educação, a exemplo de Ribeiro (2010, 20II), Neelands e Goode (2000) e Hornbrook (I998). As concepçóes teóricas são diversas e, por vezes, opostas, como afirmam Kitson e Spiby (1997), Fleming (2003) e Walkinshaw (2004). Por um lado, há autores que ainda defendem o drama na educação exclusivamente como processo, centrado na livre expressão do aluno, assim como faziam os referidos Cook, Slade e Ward; por outro, existem estudiosos, seguindo uma tendência mais contemporânea, que entendem que é preciso aproximar a atividade teatral do produto artístico, apoiando a aprendizagem técnica da linguagem teatral e a apreciação artística como partes do trabalho com teatro em escolas (RIBEIRO, 20Io). Há, ainda, autores como Schonmann (2005) e Walkinshaw (2004), que defendem a elaboração de perspectivas amplas e tolerantes, que englobem o que existe de mais positivo em cada uma das concepçóes. Identificamo-nos com essa visão mais abrangente e, por isso, fazemos uso das palavras de Walkinshaw (2004), que defende que o teatro

[...] necessita ser visto como polimorfo, fecundo, didático, dialético, pedagógico e divertido. Isso exige o reconhecimento tanto das comunalidades como das diferenças entre as diversas metodologias. [...] Somente quando o drama puder ser celebrado com todas as suas multifacetadas orientaçôes, a sua aplicação no ensino básico poderá ser tấo rica quanto o próprio assunto que lhes diz respeito. (p. I84).

\section{Teatro e educaçáo no Brasil}

Como visto na seção anterior, há registros de aplicações pedagógicas do teatro em território nacional desde o século XVI, época em que os padres jesuítas faziam uso do potencial educativo da arte teatral para a catequização dos nativos. Nossa breve exposição do ensino do teatro no contexto brasileiro, no entanto, tem como ponto de partida o início do século XX, visto que o período marca a democratização do ensino laico nas principais sociedades ocidentais. É justamente com o processo de escolari- 
zação em massa que o teatro passa a ser incluído como componente curricular da educação formal de crianças, jovens e adultos (JAPIASSU, 2009).

O ensino do teatro e também das demais linguagens artísticas (música, dança e artes visuais) é ainda hoje, no Brasil, influenciado pelas tendências "tradicionalista" e "escolanovista" que caracterizaram as práticas pedagógicas nacionais na primeira metade do século XX. Naquela época, em escolas tradicionais, o teatro era utilizado apenas em festividades escolares, na celebração de datas comemorativas. Para essas ocasiôes, os alunos realizavam apresentaçóes, para as quais decoravam textos e tinham seus movimentos cênicos rigorosamente marcados. O movimento da Escola Nova, por sua vez, também influenciou práticas pedagógicas em território nacional, especialmente entre as décadas de 1920 e i970. Conforme mencionado no item anterior, o movimento privilegiava o desenvolvimento natural da criança, e o ensino de arte, dentro dessa concepção, pautava-se por processos que davam ênfase à expressão criativa do aluno. Embora antagônicas, as correntes "tracionalista" e "escolanovista" continuam a participar de escolhas pedagógicas e estéticas no trabalho com arte dentro de escolas (PCN-Arte, BRASIL, MEC, I998).

No âmbito legal, o teatro foi pela primeira vez incluído no currículo escolar da educação básica, com a lei de Diretrizes e Bases (LDB), de I96I (lei 4.024/6I). A referida lei instituiu, de forma não obrigatória, a disciplina Arte Dramática, voltada especificamente para a linguagem teatral. Japiassu (2009) menciona que a disciplina era ministrada em alguns colégios de aplicação, escolas pluricurriculares e ginásios vocacionais. A Lei de Diretrizes e Bases de I97I (lei 5.692) incorporou obrigatoriamente o teatro ao currículo escolar, com a exigência do ensino de Educação Artística da $5^{\mathrm{a}}$ série do então $\mathrm{I}^{\mathrm{o}}$ grau (atual Ensino Fundamental) à $3^{\mathrm{a}}$ série do $2^{\mathrm{o}}$ grau (atual Ensino Médio). O título Educação Artística foi criado para nomear a atividade que visava abordar, de forma integrada, teatro, música, dança e artes plásticas. Vale mencionar que Educação Artística, na LDB/7I, era considerada "atividade artística" e não disciplina.

A inclusão obrigatória da Educação Artística no currículo escolar pode ser entendida, por um lado, como um avanço, na medida em que representa o reconhecimento do valor das artes na educaçáo. Por outro lado, não se pode deixar de levar em conta o contexto em que a lei foi promulgada e os resultados decorrentes da resolução. Historicamente, como 
se sabe, o Brasil vivia sob regime militar. Vita (1994) explica que o teatro, no contexto ditatorial, era visto como perigoso inimigo público e que as aulas de Arte Dramática, ministradas em algumas escolas, também não escapavam à desconfiança do regime: os textos teatrais trabalhados nessas instituiçóes deviam ser previamente encaminhados ao Departamento de Censura Federal. Segundo a autora, com o Ato Institucional no 5 , em I968, muitas dessas instituiçôes sofreram duras intervenções e seus professores foram aposentados. A estudiosa pondera que a conquista da obrigatoriedade da atividade Educação Artística acabou por acarretar em "[...] perda de autonomia das escolas que ofereciam ensino artístico em suas diferentes linguagens [...]" (VITA, I994, p. I5).

Nesta perspectiva, Japiassu (2009) completa que a reunião de diferentes formas de expressão estética sob uma mesma nomenclatura trouxe uma série de problemas, dentre os quais a redução da carga horária das matérias da área de artes. Antes da lei de I971, segundo o autor, muitas escolas destinavam em torno de seis horas/aula por semana ao trabalho com linguagens artísticas. Como a lei estabeleceu uma carga horária de duas horas/aula semanais para Educação Artística, os conteúdos específicos de cada uma das linguagens passaram a ter de ser trabalhados nesse curto espaço de tempo, de forma "integrada". Esse trabalho "integrado" trouxe também complicaçóes no que diz respeito à falta de professores licenciados para tal. Cursos universitários tiveram de ser criados especialmente para suprir essa demanda, formando professores licenciados em Educação Artística. Contudo, muito dificilmente um profissional conseguiria ser tão polivalente, a ponto de dominar com fluência todas as linguagens estéticas. Na prática, muitos desses novos professores acabaram por ter uma formação deficitária, e tanto eles quanto os antigos professores de uma forma específica de expressão estética acabaram por desenvolver seus trabalhos em sala de aula de maneira pouco aprofundada, apenas para cumprir o que a lei determinava. Neste contexto, desenvolveu-se a crença de que apenas com a realização de atividades expressivas espontâneas as crianças entenderiam bem cada uma das formas de arte (PCN-Arte, BRASIL, MEC, I998). Esse viés “espontaneísta” foi bastante comum no ensino de teatro no Brasil na década de I970, conforme esclarece Japiassu (2009).

No início da década de I980, a pesquisadora Ingrid Dormien Koudela, tradutora para o português da já mencionada obra Improvisação 
para o teatro (SPOLIN, 200o), realizou uma série de estudos acerca da aplicação do sistema de jogos teatrais com crianças e adolescentes. Em seu livro Jogos teatrais ${ }^{12}$, Koudela (I992) reflete que a abordagem puramente "espontaneísta" do ensino de arte "[...] corre o risco de o risco de reduzir a proposta de educação artística a objetivos meramente psicológicos, o que afasta a possibilidade de entender a arte como forma de conhecimento." (p. 25). Essa corrente de pensamento que ancora os objetivos educacionais na dimensáo psicológica do processo de aprendizagem é conhecida como "contextualista" ou "instrumental". Koudela (I992) esclarece que a abordagem "contextualista" "[...] enfatiza as conseqüências instrumentais da arte na educação e utiliza as necessidades particulares dos estudantes ou da sociedade para formular seus objetivos." (p.I7). As já mencionadas abordagens Winifred Ward, Caldwell Cook e Peter Slade, por exemplo, podem ser entendidas como "contextualistas" ou "instrumentais": a de Cook, por se utilizar do drama como ferramenta para o aprendizado de conteúdos extrateatrais; as de Ward e Slade, por apoiarem o teatro na educação como um meio para o alcance de objetivos pedagógicos amplos demais, como o desenvolvimento da "criatividade" e da "livre expressão" (JAPIASSU, 2009). Em oposição a tal abordagem, Koudela (I992) defende a linha "essencialista”, segundo a qual a arte possui um valor intrínseco e único, prescindindo, portanto, de justificativas externas à sua natureza para a aplicação em processos educacionais.

Koudela não estava sozinha na reflexão sobre o papel da arte na educação. Japiassu (2009) esclarece que no final da década de I970, o início do processo de abertura do regime autoritário possibilitou que os responsáveis pelo ensino de arte passassem a se organizar para repensar as relaçóes entre arte e educação, enfatizando a especificidade de cada linguagem artística, e defendendo a criação de licenciaturas plenas em cada uma delas. Neste contexto, surge, no início da década de I980, o movimento "Arte-Educação", que desempenhou papel fundamental nas discussôes que estavam sendo levantadas e na conscientização e mobilização de professores de arte tanto da educaçáo formal quanto da não formal (aqui entendida como externa à escola). O referido movimento tem em Ana Mae Barbosa uma de suas principais representantes. Foi ela quem desenvolveu a Proposta Triangular, que sugere que o ensino da arte seja desenvolvido em três grandes eixos: o fazer artístico, a contextualização histórica e a apreciação estética (BARBOSA, I99I). 
No ano de I988, com a promulgação da Constituição, iniciou-se uma série de discussões sobre a nova Lei de Diretrizes e Bases da Educação Nacional, que acabou por ser sancionada apenas em i996. A nova LDB (lei 9.394/96) inclui o ensino de arte como "componente curricular obrigatório" nos diversos níveis da educação básica. Os atuais Parâmetros Curriculares Nacionais (PCNs) (BRASIL, MEC, I998), elaborados após a aprovação da referida lei, deixam claro que "Arte" ${ }^{\text {I3 }}$ passa a vigorar enquanto "área de conhecimento" no currículo da escola brasileira, a ser trabalhada por meio de quatro linguagens artísticas: Artes Visuais, Dança, Música e Teatro. O documento trata de cada uma dessas modalidades separadamente, levando em conta suas especificidades, e deixa claro que as escolas podem agora optar por qual ou quais delas serão trabalhadas com maior profundidade a cada ciclo. Trata-se, portanto, de significativo avanço com relaçáo à proposta de Educação Artística, que, como já colocado, tentava "integrar" as diferentes linguagens em uma mesma aula. Com relação à carga horária destinada à área Arte, os PCNs também não estabelecem uma regra fixa, mas sugerem que haja, no mínimo, duas aulas semanais, em sequência, de cada uma das modalidades artísticas que estiverem sendo trabalhadas no ano em vigor.

Vale destacar que a mencionada Proposta Triangular é incorporada pelo documento, que ressalta, como eixos norteadores do processo de ensino e aprendizagem em Arte, a integração entre o fazer artístico, a apreciação da obra de arte e sua contextualização histórica.

Pupo (2007) explica que os PCNs não apresentam receitas de "como agir”, mas sugerem, de modo articulado, os princípios, objetivos e diretrizes que devem ser levados em conta na aprendizagem das diferentes artes. Assim, sublinha a autora, cabe ao corpo docente de cada escola - de preferência coletivamente - refletir sobre os vetores de trabalho apontados, de forma a escolher e operacionalizar propostas concretas de intervenção.

Ao abordar especificamente o teatro, os PCNs levam em conta sua origem em rituais de diferentes culturas e tempos, e conceituam o jogo a partir das fases de evolução genética do ser humano. Desse modo, conforme destaca Koudela ([200_?]), o jogo é compreendido, no documento, enquanto instrumento de aprendizagem, que promove o desenvolvimento da criatividade, em direção à educação estética e à prática artística.

Nesta análise das relaçôes entre teatro e educação no cenário nacional, é importante salientar que muitos autores brasileiros têm desenvolvido 
trabalhos de relevância no campo do teatro-educação. Segundo Japiassu (2009), desde a entrada em vigor da lei 5.692/7I, os estudos acadêmicos sobre o teatro na educação vêm se avolumando e desenvolvendo. $\mathrm{O}$ autor destaca que a produção acadêmica na área aborda, em especial, discussóes sobre as abordagens "contextualista" e "essencialista" do teatro na educação, tanto em contextos escolares quanto no âmbito da ação cultural. Neste contexto, são frequentes as pesquisas sobre práticas pedagógicas de caráter lúdico. Destacam-se, neste cenário, obras como as de Cabral (2006, 20II, 20I2), Chacra (I99i), Pupo (I99I, I997), Reverbel (I989, i997) e Vianna e Strazzacappa (200I). Não se pode deixar de mencionar, também, as contribuiçôes de Koudela (I992, I999) e Japiassu (I999, 2007, 2009), cujos estudos nos têm servido de importante referência na elaboração deste trabalho.

No entanto, a despeito de todas essas contribuiçóes no campo teórico e dos avanços na legislaçáo, o ensino do teatro - e das artes, como um todo - é, em geral, ainda pouco valorizado nas escolas. Pupo (2007), que considera os Parâmetros Curriculares Nacionais como um avanço, enfatiza que, transcorridos mais de dez anos de sua publicação, ainda havia concursos públicos envolvendo a terminologia "Educação Artística". Japiassu (2009) destaca que o ensino das artes continua sendo concebido por muitos professores, funcionários de escolas, pais de alunos e até pelos próprios estudantes como supérfluo, ligado a atividades de lazer e recreação, ou como um "luxo", permitido somente a estudantes de classes econômicas mais favorecidas.

Ainda assim, existem muitos profissionais que se propóem a desenvolver trabalhos com comprometimento e seriedade no campo das artes. No que concerne ao teatro, as linhas metodológicas seguidas por esses professores, na atualidade, são diversas, tal como atesta Japiassu (2009), que destaca pelo menos seis delas. Na prática, muitas vezes ocorre de um profissional abarcar, em seu processo de trabalho, traços de diferentes abordagens pedagógicas, atividades advindas de suas próprias experiências artísticas - visto que muitos deles são também atores - e dinâmicas por eles mesmos criadas, no dia a dia de suas aulas. A diversidade de abordagens metodológicas não se configura exatamente como um problema. Afinal, "[...] entre os caminhos possíveis, nenhum pode ser considerado, absoluta e descontextualizadamente, melhor ou superior aos outros." (JAPIASSU, 2009, p. 22). 


\section{Consideraçóes finais}

Como se viu, as relações entre teatro e educação são discutidas e exploradas desde a Antiguidade. O contexto histórico de cada época influenciou as diferentes práticas pedagógicas e a diversidade de maneiras de se pensar o drama em contextos educativos. Para uma compreensão mais abrangente do tema, recomendamos a leitura de Berthold (2006), Courtney (I980) e Japiassu (2009). A primeira autora apresenta ao leitor um vasto panorama a respeito da história do teatro no mundo, que auxilia no entendimento de como a arte teatral se desenvolveu ao longo do tempo, em diferentes regióes do planeta; o segundo autor explora as relaçóes entre teatro e jogo, buscando suas raízes históricas, com base nos principais pensadores que teceram consideraçóes a respeito do tema; e o terceiro traça um esclarecedor painel do ensino do teatro no Brasil na pós-modernidade, abordando as principais correntes pedagógicas aplicadas a essa arte, e contextualizando-as historicamente.

Objetivamos com este artigo fornecer um breve panorama das relaçóes entre teatro e educação ao longo da História, apontando para a pluralidade das potencialidades pedagógicas dessa arte. A visão histórica indica que o teatro quase sempre foi concebido como um excelente aliado à educação, por mais distintas que fossem as épocas e mais diversos os objetivos pedagógicos. No contexto brasileiro, os atuais Parâmetros Curriculares Nacionais (BRASIL, MEC, I998), elaborados na esteira da Lei de Diretrizes e Bases (lei 9.394/96), levam em conta a origem do teatro em rituais de diferentes culturas e tempos, e reconhecem sua importância singular no campo educacional. Não se concebe, portanto, que se perpetue a desvalorização de sua relevância dentro das escolas brasileiras, especialmente em um contexto em que tanto se debate a importância na reformulação dos currículos nacionais, tendo em vista a formação dos indivíduos para a cidadania. A valorização e o aprimoramento da prática teatral na escola básica demandam vontade política e aprofundado debate, cuja dimensão, evidentemente, não alcançaríamos neste curto artigo. Ainda assim, acreditamos que o conhecimento da multiplicidade teórica e metodológica do teatro na educação pode auxiliar na elaboração de políticas públicas adequadas ao sistema educacional brasileiro, e esperamos, com 


\section{este trabalho, ter partilhado nosso entendimento da arte teatral enquanto amplo campo a ser explorado com fins educacionais.}

\section{Notas}

I Mistério: drama medieval, representado por ocasião das festas religiosas, em que se encenavam episódios da Bíblia (Antigo e Novo Testamento) ou da vida de santos. Costumava durar vários dias e era encenado por atores amadores, sob a direção de um condutor, em cenários simultâneos, denominados "mansôes" (PAVIS, I999).

2 Moralidade: obra dramática medieval, de inspiração religiosa e intuito didático e moralizante, em que vícios e virtudes eram personificados, alegoricamente (PAVIS, I999).

3 Por vezes, esses textos eram motivo de controvérsias de ordem religiosa e política: religiosa, pois a recente Reforma Protestante gerava manifestaçôes, tanto favoráveis quanto desfavoráveis, por vezes exacerbadas; e política, por tratar de fraquezas nacionais e levantar suspeitas de conspiração. Professores e reitores que tocaram nesses temas polêmicos sofreram retaliaçốes e, em alguns casos, chegaram a ser presos, a exemplo de Philipp Nikodemus Frishlin, na regiáo da atual Eslovênia, e Johannes Messenius, na Suécia. A opção por textos da Antiguidade e também por temas religiosos do Velho Testamento acabou por se tornar recorrente, tendo em vista que era uma maneira de salvaguardar alunos e professores de conflitos religiosos e políticos (BERTHOLD, 2006).

4 A Dinastia dos Tudor reinou na Inglaterra entre os anos de I485 e I603. A última monarca dessa casa real foi a rainha Elizabeth I, sob cujo reinado viveram poetas e dramaturgos como William Shakespeare, Christopher Marlowe e Ben Jonson (KOZUKA; MULRYNE, 2006).

5 Dentre os jesuítas que viveram no Brasil, destaca-se José de Anchieta, autor de uma série de peças teatrais, tais como o Auto da pregação universal, o Auto de São Lourenço, o Auto do crisma e o Auto de Santa Úrsula.

6 Isso ocorreu, principalmente, na educação de crianças do sexo masculino. Courtney (I980) faz uma ressalva no que diz respeito à educação feminina, na Inglaterra. Nesse país, a educação das meninas, que seguia o modelo francês, incluía teatro e dança. Na França, é interessante destacar, durante os séculos XVII e XVIII, meninas do convento de Saint Cyr improvisavam diálogos e representavam peças de Corneille e Racine. Dois textos teatrais deste último autor, inclusive, foram escritos especialmente para elas. As meninas chegaram a representar diante de Maria Antonieta, mas, antes da Revolução, o teatro escolar foi suprimido no país, apesar de Rousseau defender o jogo na educação e de Voltaire apoiar o teatro.

7 Japiassu (2009) faz uma clara distinção entre jogo dramático e jogo teatral, baseado na etimologia das palavras "drama e teatro": a primeira, de origem grega, significa "eu faço, eu luto" (SLADE, I978, p. I8); já a segunda, deriva do vocábulo gregro theatron, cujo significado é "local de onde se vê" (plateia). O jogo dramático, portanto, seria aquele em que todos "fazem", ou seja, todos participam da ação imaginária, não havendo espectadores. Crianças imersas em brincadeiras de "faz-de-conta", por exemplo, estão realizando jogo dramático. O jogo teatral, por sua vez, é intencional, e pressupóe a existência tanto de "jogadores" quanto de "observadores". Dentro de uma abordagem piagetiana, Koudela ( 1992 ) explica que "o processo de jogos teatrais visa efetivar a passagem do jogo dramático (subjetivo) para a realidade objetiva do palco" e que essa passagem "[...] pode ser comparada com a transformação do jogo simbólico (subjetivo) no jogo de regras (socializado).” (p. 44). A autora esclarece, ainda, que enquanto no jogo dramático há a assimilação pura da realidade, no jogo teatral ocorre um esforço de acomodação, quando se buscam soluçôes para problemas da atuação.

8 Conforme esclarece Japiassu (2009), o "psicodrama” "[...] se ocupa das relaçóes interpessoais e da psicologia da vida privada do paciente [...]", enquanto que o "sociodrama" "[...] investiga as relaçóes intra e intergrupais, com base nos valores culturais do grupo social ao qual pertence 
o paciente." (p. 35). O autor explica ainda que são, ambas, formas de terapia em que os pacientes são tratados em grupo e que, historicamente, romperam com o tratamento baseado no depoimento verbal do indivíduo isolado, típico da psicanálise freudiana. A ênfase de Moreno à espontaneidade, à criatividade e ao trabalho em grupo foram fatores que favoreceram a incorporação terapia psicodramática à educação.

9 As peças didáticas de Bertold Brecht fazem parte de suas primeiras obras dramatúrgicas. Foram a princípio concebidas para serem trabalhadas por grupos de operários ou por crianças e jovens, em escolas. Desgranges (20II) coloca que a iniciativa, na medida em que propunha um trabalho com amadores, visava a uma democratização do teatro. O mesmo autor explica que as peças didáticas estariam fundamentadas “[...] na ideia de que os atuantes ensinam a si mesmos, a partir do questionamento provocado pela ação dramática, da crítica à situação social que os envolve e da reflexão sobre suas atitudes diante dos fatos abordados na peça." (DESGRANGES, 20I I, p. 82). Desse modo, pode-se dizer que o principal objetivo das peças didáticas de Bertold Brecht não é sua encenação, mas a conscientização daqueles que nelas atuam.

Io $\mathrm{O}$ teatro do oprimido consiste em uma série de procedimentos baseados na improvisação teatral, que pretende, por meio da conscientização política do público, transformar a visão sobre as relaçóes tradicionais de produção material nas sociedades capitalistas (BOAL, I979). Trata-se de uma poética teatral inspirada na estética brechtiana e na pedagogia libertadora de Paulo Freire. No teatro do oprimido, há uma democratização do acesso ao palco, já que o espectador tem papel ativo nas encenações, convertendo-se em "espetATOR" (JAPIASSU, 2009).

I I A “terapia social da performance" - ou "psicologia performática” - diz respeito a "[...]uma prática terapêutica que utiliza de modo sistemático a linguagem teatral ou a performance como recurso para o crescimento afetivo e social do sujeito, objetivando o seu desenvolvimento cultural." (JAPIASSU, 209, p. 60). Ancora-se na perspectiva sócio-histórica da psicologia, postulada por Lev Vygotsky, que trabalha com a concepção de que o homem se constitui enquanto ser humano nas relaçóes que estabelece socialmente (OLIVEIRA, I993). Tem como objetivo construir "zonas de desenvolvimento proximais emocionais" - conceito claramente apropriado da abordagem vygotskiana -, em que as pessoas sejam apoiadas "[...] a fazer o que se encontra além de suas possibilidades atuais [...], a atuar na perspectiva de quem estão se tornando." (NEWMAN; HOLZMAN 2003, p. 7). Dessa forma, pretende-se desafiar os sujeitos a abandonar concepçóes fixas e definitivas de acerca de seus papéis, estágios e identidades.

I2 A obra Jogos Teatrais é originada da dissertação de mestrado da referida pesquisadora, defendida no ano de I982, na Escola de Comunicação e Artes, da Universidade de São Paulo.

I3 A grafia "Arte" aparece nos atuais Parâmetros Curriculares Nacionais (BRASIL, MEC, I998) quando se trata especificamente da área curricular; nos demais casos, é utilizada a grafia "arte”..

\section{Referências}

BARBOSA, Ana Mae. A imagem no ensino da arte: anos oitenta e novos tempos. Sáo Paulo: Perspectiva; Porto Alegre: Fundação IOCHPE, I99r.

. Arte/Educação contemporânea: consonâncias internacionais. São Paulo:

Cortez, 2005 .

; CUNHA, Fernanda Pereira. Abordagem triangular no ensino das artes e

culturas visuais. São Paulo: Cortez, 20 Io.

BOAL, Augusto. Técnicas latino-americanas de teatro popular. São Paulo: Huicitec,

I979. 
BERTHOLD, Margot. História mundial do teatro. Tradução Maria Paula Zurawski, J. Guinsburg, Sérgio Coelho e Clóvis Garcia. 3. ed. Sáo Paulo: Perspectiva, 2006. BRASIL. Parâmetros curriculares nacionais. Brasília: MEC/SEF, I998.

BRASIL. Lei de diretrizes e bases da educação nacional. Lei n ${ }^{\circ} 9394$, de 20 de dezembro de I996. Estabelece as diretrizes e bases da educação nacional. Brasília, DF, I996.

CABRAL, Beatriz Ângela Vieira. Açáo cultural e teatro como pedagogia. In:

Revista Sala Preta. São Paulo: Departamento de Artes Cênicas, ECA-USP, v. I2, n. I, 20I2. Disponível em: <http://www.revistasalapreta.com.br/index.php/salapreta/ article/view/4I4/404>.

Acesso em: I9 nov. 2012.

. Drama como método de ensino. São Paulo: Hucitec, 2006.

. O jogo teatral no contexto do drama. In: Fênix - revista de história e estudos culturais. v. 7, ano VII, n. I, jan./fev./mar./abr. 20I I. Disponível em: <http://www. revistafenix.pro.br/vol22beatriz.php>. Acesso em: I6 set. 2012.

CHACRA, Sandra. Natureza e sentido da improvisação teatral. São Paulo: Perspectiva, I99..COOK, Caldwell. The play way. London: Heinemann, I917.

COURTNEY, Richard. Jogo, teatro e pensamento: as bases intelectuais do teatro na educação. Tradução Karen Astrid Müller e Silvana Garcia. Sáo Paulo: Perspectiva, I980.

DORA TO, Lai-wa et al. Reflections on a primary school teacher professional development programme on learning English through Process Drama. In: Research in Drama Education: The Journal of Applied Theatre and Performance, v. I6, n. 4, p. 5I7-539, $201 \mathrm{I}$.

DUNN, Julie; STINSON, Madonna. Not without the art!! The importance of teacher artistry when applying drama as pedagogy for additional language learning. In: Research in Drama Education: The Journal of Applied Theatre and Performance, v. I6, n. 4, p. 617-633, 2011 .

EVEN, Susanne. Drama grammar: towards a performative postmethod pedagogy. In: The Language Learning Journal, v. 39, n. 3, p. 299-312, 201 I.

FLEMING, Mike. Starting Drama Teaching. 2. ed. London: David Fulton, 2003. GOHN, Maria da Glória. Educação não formal e o educador social. São Paulo, Cortez: 2010. . Movimentos sociais e educação. 8. ed. São Paulo: Cortez, 2012. 
HORNBROOK, David. Drama and Education. In: On the Subject of Drama. London: Routledge, I998.

JAPIASSU, Ricardo. A linguagem teatral na escola: pesquisa, docência e prática pedagógica. Campinas: Papirus, 2007.

. Metodologia do ensino de teatro. 8. ed. Campinas: Papirus, 2009.

- O ensino do teatro nas séries iniciais da educação básica: a formação de conceitos sociais no jogo teatral. Dissertação (Mestrado em Artes Cênicas) - Escola de Comunicação e Artes (ECA), Universidade de São Paulo, São Paulo, I999.

KAO, Shin-Mei; CARKIN, Gary; HSU, Liang-Fong. Questioning techniques for promoting language learning with students of limited L2 oral proficiency in a dramaoriented language classroom, Research in Drama Education: The Journal of Applied Theatre and Performance, v. I6, n. 4, p. 489-5I5, $201 \mathrm{I}$.

KASSAB, Yara. As estratégias lúdicas nas ações jesuíticas, nas terras brasílicas (I549I597), "para a maior glória de Deus". Tese (Doutorado em História Social)- Faculdade de Filosofia, Letras e Ciências Humanas, Universidade São Paulo, São Paulo, 20 ıo.

KOUDELA, Ingrid Dormien. A nova proposta de ensino do teatro. Disponível em: <http://www.eca.usp.br/prof/ingrid/site/pdf/novapropostadeensino.PDF>. Acesso em:

29 fev. 2012 .

. Jogos teatrais. 3. ed. São Paulo: Perspectiva, I992. 
O’MALLEY, John W. Os primeiros jesuitas. Tradução Domingos Armando Donida. Sáo Leopoldo: Editora Unisinos; Bauru: EDUSC, 2004.

PAVIS, Patrice. Dicionário de teatro. Tradução J. Guinsburg e Maria Lúcia Pereira. São Paulo: Perspectiva, I999.

PUPO, Maria Lúcia de Souza Barros. Entrevista com Maria Lúcia Pupo. 2007.

Entrevista concedida à Revista da Móbile. Disponível em: <http://www.escolamobile. com.br/arquivos/20I I/geral/espaco-reflexao/revistas-mobile/2007/entrevista.pdf>.

Acesso em: 29 fev. 2012.

. No reino da desigualdade. São Paulo: Perspectiva, I99I.

. O lúdico e a construção do sentido. In: Sala Preta. São Paulo:

Departamento de Artes Cênicas, ECA-USP, v. I, pp. I8I-I87, jun. 200 I.

- Palavras em jogo: textos literários e teatro-educação. Tese (Livre Docência) -

Escola de Comunicação e Artes (ECA), Universidade de São Paulo, São Paulo, I997.

REVERBEL, Olga. Jogos teatrais na escola. São Paulo: Scipione, I989.

. Um caminho do teatro na escola. 2. ed. São Paulo: Scipione, I997.

RIBEIRO, Delfim Paulo. As convenções dramáticas como instrumento estéticopedagógico. Exedra. n. 5, p. 93-IOI, $201 \mathrm{I}$.

. O princípio da conexão ausente: dinâmicas não-lineares no campo

epistemológico e curricular do drama na educação. Tese (Doutorado) - Departamento de Didáctica e Organización Escolar, Universidade de Santiago de Compostela, Santiago de Compostela, 20 io.

SANTOS, Ricardo Costa dos. A influência da farsa medieval francesa na concepção do teatro farsesco de Gil Vicente: a farsa do maître Pathelin e a comédia chamada $A$ farsa de enganos. Congresso Internacional da ABRAPLIP, 22, 2009.

SCHONMANN, Shifra. "Master" versus "Servant": Contradictions in Drama and Theatre Education. The Journal of Aesthetic Education. v. 39, n. 4 (Winter), p. 3I-39, 2005 .

SLADE, Peter. Child Drama. London: University of London Press, I954.

I978. . O jogo dramático infantil. Tradução Tatiana Belinky. São Paulo: Summus,

SPOLIN, Viola. Improvisação para o teatro. Tradução Ingrid Dormien Koudela e Eduardo Amos. 4. ed. São Paulo: Perspectiva, 2000.

- Jogos teatrais: o fichário de Viola Spolin. Tradução Ingrid Dormien Koudela.

Sáo Paulo: Perspectiva, 200ı. 
TOLEDO, Cézar de Alencar Arnaud de; RUCKSTADTER Flávio Massami Martins; RUCKSTADTER Vanessa Campos Mariano. O teatro jesuítico na Europa e no Brasil no século XVI. In: HISTEDBR On-line, Campinas, n. 25, p. 33-43, mar. 2007. Disponível em: < http://www.histedbr.fae.unicamp.br/revista/edicoes/25/arto3_25.pdf >. Acesso em: 29 fev. 2012.

VIANNA, Tiche; STRAZZACAPPA, Márcia. Teatro na educação: Reinventando mundos. In: FERREIRA, Sueli (Org.). O ensino das artes: construindo caminhos. Campinas: Papirus, 200I.

VITA, Marly de Jesus Bonome. Histórias da história do teatro aplicado à educação. Dissertação (Mestrado em Artes Cênicas) - Escola de Comunicação e Artes (ECA), Universidade de São Paulo, São Paulo, I994.

WALKINSHAW, Agnes. Integrating Drama with Primary and Junior Education: The Ongoing Debate. New York: The Edwin Mellen Press, 2004.

WARD, Winifred. Playmaking with children from kindergarden to high-school. New York: Appleton-Century-Crofts, I957.

Recebido em I2 mar. 20I2 / Aprovado em 25 set. 2012 Para referenciar este texto HANSTED, T. C.; GOHN, M. G. Teatro e educação: uma relação historicamente construída. EccoS, São Paulo, n. 30, p. 199-220. jan./abr. 2013. 